\title{
A Panoptical View of Womanhood in Amitav Ghosh's Select Fiction
}

\author{
M. R. Ramya \\ Assistant Professor, Department of English, Vellalar College for Women, Erode, Tamilnadu; ramyamadhu2@gmail.com
}

\begin{abstract}
Feminism is a much argued topic in the past and present centuries wherein woman are shown to be suppressed, oppressed, smothered, controlled, governed, dominated and subjugated. The scenario continues to persist and myriad writers have brought to light the sufferings of women in their works But only some writers in their portrayal of women subjugation acknowledge the strength of women to withstand sufferings and their incumbent boldness to handle life. Amitav Ghosh, an accomplished Indian English writer, stands among the few to voice out the subaltern voices. His kaleidoscopic view communicates the impact on social, cultural, economic and psychological aspects of people from different social set-up and age. His Ibis trilogy encompassing, Sea of Poppies (2008), River of Smoke (2011) and Flood of Fire (2015), set in the precincts of the First Opium War, brings to the fore the colonial desire of the British in promulgating the opium trade between India and China thereby vandalizing the material and cultural wealth of the nations, for its monetary benefits. This paper aims to highlight the voices of women in the first two novels of the trilogy, Sea of Poppies and River of Smoke.
\end{abstract}

Keywords: Boldness, Feminism, Opium, Subaltern, Suppression

\section{Introduction}

The novel, Sea of Poppies, envisions the fate of indentured labourers and convicts embarked in the slave schooner, Ibis, to Mauritius to escape the different travails they face in India. The second novel, River of Smoke, opens with Deeti, the central character in Sea of Poppies and a description of her shrine in Mauritius. The shrine happens to be different in the way that it includes not only deities of worship but also painted walls of life figures who have had a larger impact on Deeti's life and on her fellow convicts-Paulette, Neel, and Ah Fatt, who travelled along with her in the Ibis. The whole novel is a revelation of the lives of characters in the walls through which we are introduced to the women in their lives.

\section{Womanhood at its Helm and The Cult of Transformation}

Deeti is a true figure of transformation in the story. Married to Hukam Singh, an opium addict, she is forced to spend a life of isolation mentally and physically. Her only solace is her daughter, Kabutri, whose presence helps her to work hard in the small land of her husband's inheritance cultivating opium to meet the expenses of the family. She receives the first blow of life as she gets to know the truth behind the consummation of her marriage by Chandan Singh, her brother-in-law with the help of his mother to conceal Hukam's impotency. Life takes a serious turn as her husband dies of addiction and Chandan's advances leaves her scattered. Sending Kabutri to live with her brother, she 
takes the bold stance of Sati. Saved from it by Kalua, an outcaste, they together wander the nearby city begging for food. Amidst all the odds, she stays positive, "when the sun rises the path will show itself-and strongly did she believe this that not even at the worst of times did she allow her hopes to slacken" (203). ${ }^{1}$

Deeti boards Ibis with him to escape her family's outrage and in the ship, she acts as a guardian to the varied women and helps them dispel their distress emboldening them with confidence. As fate follows her close by, troubled by the plan of Bhyro Singh from Deeti's village to kill Kalua, he escapes from the ship along with a few men in a boat leaving Deeti alone with his child. "Stars and planets, after all, travelled on predictable orbits-but the wind, nobody knew where the wind would choose to go. The wind was the power of change, of transformation...it was the wind that had decided it was her karma to be carried to Mauritius, into another life" $(19)^{2}$. She starts a new life in Mauritius with her son and thereby becomes a matriarch to the families of the indentured labourers.

Paulette, the daughter of a botanist, Pierre Lombart, born and brought up in India is sturdy enough to stick on to her ideals. Her father's sudden demise leaves her under the care of Mr. Burnham, the owner of Ibis. Unable to get along with the English household, and his plan to get her married to an elderly Englishman, she prepares to take the ship, Ibis in the hope of finding a better future as a botanist. She pursues to travel the world as her grand-aunt in the guise of a man and seeks help from Zachary Reid, secondmate of the ship. But sensing the troubles she may face, he tries to finance her for a travel in another ship. With her urgency to escape the marriage proposals, she retorts back, "It's not your charity I want, Mr.Reid,... Do you think a few little obstacles would have stopped my grand-aunt from making her voyage?...Oh, so that is it-a girl cannot do it?... But you are wrong: I can do it and I will" $(31)^{1}$.

Finally she boards the ship with the help of $\mathrm{Mr}$. Burnham's gomusta, Baboo Nob Kissin, veiling herself as an Indian woman. Landing in the Mauritius, with the help of Zachary's men, she disguises herself as a man and lives in the Botanical Gardens near Port Louis. Her determination merged with fate, she is identified by Mr. Frederick Penrose, a nurseryman from England in the Gardens and is offered a place in his ship, Redruth as a horticulturalist. She joins him in his pursuit of locating a rare plant, Camelia in China and lives her aspirations.

Malati, the wife of Neel Ratan Halder, the zamindar of Rakshali estate is a woman, who amidst all the hardships in her life holds her spirits high. Being an obedient and a tranquil wife, after Neel being imprisoned for forgery and his properties seized, there is a total change in her attitude. On her visit to meet Neel in the prison, he was so worried seeing his family's plight. "But the shame, he said. Are you sure you will be able to bear it?" (269)1. For which she answers after further discussion, "Don't worry about us; we'll manage. It's you who must be strong" $(270)^{1}$. He promises them to return after seven years of his imprisonment and take them to a new place to start a new life.

Later in the second novel after his escape to Canton from Ibis, he encounters Baboo Nob Kissin and gets to know from him about his family that in spite of his declared death in his hometown, she is unshakable in her belief that Neel is alive. "She has managed better than you would think. She teaches your boy his letters and some of the local children too. Neither your wife nor your son doubt for a moment that you will return" (398) ${ }^{2}$. Bob's response about his wife and son leaves him stunned. Recalling her visit in the prison he adjudges her true personality now. "Not till then did he realize that the girl he had married had grown into a woman of uncommon beauty" $(398)^{2}$. The beauty he mentions here could be attributed to her endurance and perseverance.

Two other women who travel along their life with willpower are Marianne Chinnery, wife of George Chinnery and Sundaree, his mistress. George is a man of escapism, who often flees from a place to one of comfortability. Earning a great wealth out of his paintings in Calcutta, he lavishes a lot of luxuries on his mistress, Sundaree and keeps her with their two sons in the outhouse of his grandiose bungalow. The situation changes significantly, when his other family from Britain is to join him. They are packed off to a dwelling far away and provided with a meager amount for their livelihood. When Marianne finds about her husband's other family, instead of accusing him, she christens them with their family names and sees to that he acts as a dutiful father to them teaching his art. The interlude lasts only for a short time as George flees the city ditching both the families. Marianne too flies back to London to live with her daughter's family after her son's demise. But Sundaree being an indefatigable personality, “...despite all the difficulties, she had done what she could to ensure the continuation of her sons' training in the arts" (138-39)2. Robin, her second son later becomes an artist as his father.

\section{Conclusion}

The noted female characters in the novels give out the true definition of feminism that, rather than fighting for one's rights, standing for oneself would bring in the needed change. Though their destiny roots them out of places or 
turns upside their comfortable stances of life, the women travel along the destined path and win it over. Especially, the task of motherhood makes them headstrong in overcoming the ordeals of life. As a great fire is ignited from a sparkle, a complete change is to be awaited and relished. These distinct personalities clearly notify that only the power of mind would bring a total transformation in life.

\section{References}

1. Amitav G. Sea of Poppies. Gurgaon: Penguin Books; 2009.

2. Amitav G. River of Smoke. New Delhi: Penguin Books; 2011. 